\title{
A TARTALOM ÉS FORMA KAPCSOLATA A KEREKESSZÉKEK VONATKOZÁSÁBAN
}

\author{
Molnár Fanni Csilla \\ hallgató, Miskolci Egyetem, Gép-és Terméktervezési Intézet \\ 3515 Miskolc, Miskolc-Egyetemváros, e-mail: Molnar.fanni.csilla@gmail.com
}

Tóbis Zsolt

mesteroktató, Miskolci Egyetem, Gép-és Terméktervezési Intézet

3515 Miskolc, Miskolc-Egyetemváros, e-mail: machtzs@uni-miskolc.hu

\begin{abstract}
Absztrakt
A tartalom és a forma kapcsolata a kerekesszékek világában is tetten érhetö, ezt szeretnénk a következökben közelebbröl megvizsgálni. Egy rövid történeti áttekintés és fejlödéstörténet után ismertetjük a két alapvetö, kézzel hajtott kerekesszék-csoporttal szemben állitott követelményeket, majd részletesen bemutatjuk a tartalom és forma kapcsolatát a különbözö kerekesszék-változatok példáján keresztül.
\end{abstract}

Kulcsszavak: standard kerekesszék, aktív kerekesszék

\section{Abstract}

The relationship between content and form can also be seen in the world of wheelchairs, and we would like to take a closer look at this in the following. After a brief historical overview and history of development, we describe the requirements for the two basic groups of hand-operated wheelchairs, and then detail the relationship between content and form through the example of different wheelchair variants.

Keywords: standard wheelchair, active wheelchair

\section{A kerekesszékek története}

A kerekesszék nem mai találmány az időszámítás előtti időkből is van fennmaradt emlék. Az idők során folyamatosan fejlődött, tökéletesedett az eszköz, és egyre sokszínűbbé, változatosabbá vált a termékválaszték, és megjelentek a speciális igények kielégítésére alkalmas darabok.

A következőkben pontokba szedve követhetjük végig a kerekesszékek fejlődését.

„A kerekesszékek története: [2]

- időszámítás elötti 6. század: kerekesszék szerủ eszköz rajza egy kínai szarkofágra vésve;

- 16. század: II. Fülöp kézzel és lábbal hajtott gördülő mozgatható kerekesszéke;

- 1700 körül XIV. Lajos egy ún. "roulette"-et használt mütéte utáni felépülésének idejében;

- 18. század: az első maihoz hasonló kialakítású kerekesszék (nagy elülső fa kerékkel és kis hátsó görgővel);

- 19. és 20. század: Az Amerikai Függetlenségi Háborút és az I. Világháborút követő fakerekü kerekesszékek vesszőfonat üléssel, állítható kar- és lábtartóval;

- 1867. A fa kereket felváltja az acél;

- 1875. A felfújható gumikerék megjelenése;

- 1894. Fix keretre szerkesztett kerekesszék, kemény vesszőfonatból, nagy hátsó kerékkel az önálló hajtáshoz; 
- 1933. Herbert Everest és Harold Jennings fém kereszt-merevítésű kerekesszéke (E\&J);

- 1937. Keresztben összecsukható keretü kerekesszék (Sam Duke);

- 1950. Everest \& Jennings első elektromos kerekesszéke (tranzisztoros);

- 1952. A kerekesszékes sport elterjedése (Stoke Mandeville Rehabilitációs Központ);

- 1964. Az első Paralimpiai Játékok - Tokyo, Japán;

- 1970-1980. - a könnyüvázas önhajtós kerekesszékek forradalma (sporttevékenységek);

- 1975. Bob Hall kerekesszékkel teljesíti a maratont Bostonban;

- 1980-as évek microprocessor-vezérelt irányítású elektromos kerekesszék;

- 1980-1990. az elektromos kerekesszék mai jellemzőinek kialakulása.” [2]

A legelső kerekesszékek minden tekintetben úttörőek voltak, ám meghatározóan a sérült személy hordozhatósága, illetve közlekedésének lehetővé tétele jellemezte, és nem sok szerep jutott a személyre szabottságnak, egyéni igények kiszolgálásának. Kialakításuk maximálisan a főfunkció, vagyis a mozgásában korlátozott személy közlekedésének, illetve szállításának kiszolgálására volt megalkotva. Egyszerü elemekből és anyagokból építették fel, a kényelem, és a megjelenés másodlagos szempont voltak [1. ábra].

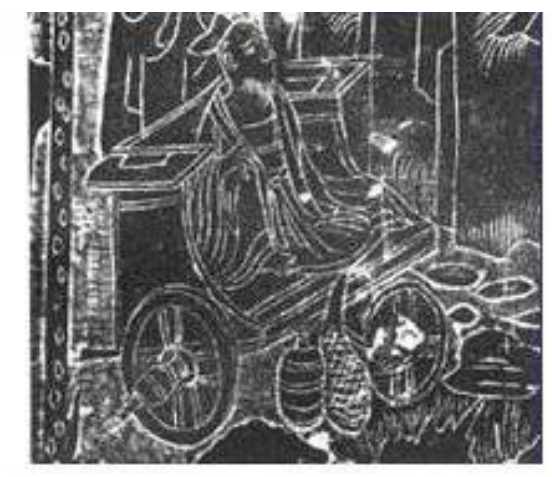

1. ábra. Elsö fennmaradt emlék kerekesszék ábrázolásáról - kínai szarkofág, i.e. 6. szd. [7]

Az évek múlásával, az orvostudomány, valamint a technika fejlődésének köszönhetően egyre tudatosabban megtervezettek, egyre inkább személyre szabhatóak és kényelmesebbek a kerekesszékek, ami nagyban megkönnyíti a felhasználó dolgát. Manapság egy gyógyászati segédeszközboltba besétálva az ember igényeit alaposan felmérve, és a test adott méreteit lemérve minden megrendelö számára egyénre szabott kerekesszéket gyártanak le, ami az ő számára optimális kialakítással bír. Aki azonban ezen felül is extra kívánságokkal áll elő, legyen az kisebb átalakítást igénylő kialakítás, vagy akár egészen extrém elvárás, találni fog megoldásokat. A kerekesszékek ezen változatosságát és sokszínüségét szeretném most példák segítségével bemutatni.

Első lépésként néhány alcsoportot megalkotva igyekszem rendszerezni az egymástól olykor nagyban különböző darabokat, majd az adott csoporton belül részletezem a sajátságos megoldásokat, egyedi jegyeket, jellegzetes vonásokat, és a kiegészítő funkciókat. Mindezt a dizájn szempontjából fontos tartalom és forma kapcsolat szem előtt tartásával teszem.

\section{A kerekesszékekkel szemben állított követelmények jegyzéke}

Ahogyan korábban már volt szó róla, a kézzel hajtható kerekesszékek alapvetően két csoportba soroljuk: standard és aktív. Elvétve szó eshet a „félaktív kerekesszékek” csoportjáról, ami az előzőek ötvözete, azonban a hivatalos csoportosítás ez utóbbit nem tekinti külön kategóriának. Így maradok az eredeti két 
kategóriánál, és szeretném bemutatni azokat a tulajdonságokat, amelyek a két fôcsoporttal szemben állított követelményként jelentkeznek.

Az OttoBock cég kiemelkedik kiváló minőségü kerekesszékeivel, rendkívül széles választékával, ezen túl piacvezető a mozgássérültek számára készülő egyéb termékek területén is. Mottója sokat elárul a vállalat filozófiájáról: „Quality for life” azaz „Minőség az élethez”.

\subsection{Standard kerekesszékek csoportja [1]}

A standard kerekesszékek jelentik az alap verziót, kicsit nehezek, kicsit lomhák, kicsit nehezebb velük manőverezni, azonban strapabíróak, megfizethetőek, és rengeteg embernek könnyítik meg az életét. A standard kerekesszékekkel szemben állított követelmények és egyéb jellemzők röviden bemutatva a következők:

- Fordulékonyság, hogy mind a mozgássérült személy, mind a kísérő személy könnyen, kis erőfeszítéssel tudjon irányt változtatni, egy helyben fordulni, kanyarodni.

- Jó irányíthatóság, ami az előzővel valamelyest összefügg, itt azonban a helyes iránytartásról, pályakövetésről van szó. Ehhez feltétel, hogy jól be legyenek állítva a kerekek, és ne legyen nehéz adott esetben összehangolni ezek szinkron fordulását.

- A kis tömeg nem elvárás, nem is jellemzö, de vannak könnyebb szerkezetek is köztük;

- Összecsukhatóság, ami a könnyü szállítást és tárolást teszi lehetővé.

- Billentőtaposó a kísérő személy számára, hogy könnyebben fel tudja tenni kisebb padkákra, lépcsőfokokra.

- Masszív, strapabíró konstrukció, hogy a használat során történő váratlan erőbehatások, „koccanások", kisebb ütközések, borulások ne okozzák az eszköz olyan mértékü sérülését, ami az eredeti funkció betöltését lehetetlenné tenné. Ez fontos, hiszen a mindennapos használat során ezek a kisebb balesetek elkerülhetetlenek, föleg a sokak által közösen használt kerekesszékek esetében, mint például a kórházakban, egészségügyi centrumokban használt darabok.

- Bátran terhelhető, magasabb a terhelési korlát: bizonyos darabok engedéllyel akár 300 kg tömegü pácienseket is ki tudnak szolgálni, alapvető elvárás a nagy terhelhetőség;

- Megfizethető ár, hogy a rászoruló emberek számára elérhető legyen. Orvosi döntés alapján támogatás is kapható bizonyos darabokra.

- Kötöttek a méretek, egyedül a beülő szélesség személyre szabott, ám itt is összesen hat különböző méret közül kell kiválasztani a leginkább megfelelőt.

\subsection{Az aktív kerekesszékek csoportja [1]}

Aktív kerekesszéket olyan emberek használnak, akik aktív életmódot folytatnak, tanulnak, vagy dolgozni járnak, gyerekeket nevelnek, háztartást vezetnek, sőt akár rendszeresen sportolnak is. Az ő számukra került kialakításra az aktív kerekesszék, a kerekesszékek következő generációja.

Az aktív kerekesszékekkel szemben állított követelmények és egyéb jellemzők röviden bemutatva a következők:

- Kisebb tömeg: átlagosan 10 kg-nál kezdődnek, de természetesen vannak köztük könnyebbek is, nehezebbek is.

- Fordulékonyabb, a helyben történő fordulás minimális energiabefektetést igényel;

- Általában nincsen karfája, hiszen ezen felhasználók aktív életmódot élnek, sokat közlekednek, a kartámasz pedig valamilyen mértékben mindenképpen akadályozza a hajtást, hiszen pont útban lenne); 
- Általában nincsen fölszerelve tolókar, hiszen ezek az emberek önálló életet élnek, nincsen szükségük „,külsős” segítségre. Ezzel is - ha csupán egy kicsivel is - csökken az eszköz össztömege, és ez természetesen minden olyan elemre vonatkozik, ami a standard kerekesszékeknél megtalálható, de az aktív kerekesszékeknek nem része;

- Meghatározott felső korlát (azonban 120 kg-ot ezek a kerekesszékek is el tudnak hordozni, vannak köztük még nagyobb teherbíró képességgel rendelkezők, de nem ez a meghatározó);

- Mozgékonyabb, ami részben a kisebb mozgatott tömegnek köszönhető, részben pedig a magasabb szintü technológiai kialakításnak;

- Jobb minőség a professzionálisabb alapanyagoknak, alkatrészeknek és gondosan megtervezett konstrukciónak köszönhetően;

- Választható méretek, személyre szabott kialakítás, pontosan beállított méretek jellemzik a maximális felhasználói élmény elérésére, és a lehetö legkényelmesebb, és legkisebb energiabefektetést igénylő használatra.

- A kerekek általában egy mozdulattal kivehetőek, ami a könnyebb szállíthatóságot teszi lehetővé, így ugyanis egy kisebb csomagtartóba is könnyen berakható. Ezen kívül azok a felhasználók, akik maguk is autót vezetnek, a beszállás után könnyebben be tudják tenni a kerekesszéket a szomszédos ülésre, ha előbb a kerekeket ki tudják pattintani, és utána már csak a kicsire összehajtott vázat kell beemelni.

- Formatervezettebb, esztétikailag igényes, többnyire gondosan formatervezett darabok. Ez részben azt a célt is szolgálja, hogy minél személyre szabottabb, minél egyedibb darabokkal tudják kiszolgálni a vásárlóközönséget, akik egy ilyen, a saját ízlésüknek megfelelően kialakított darabot jobban magukénak tudnak érezni, és ezzel is ki tudják fejezni magukat, akárcsak bárki más például az autójával, vagy az öltözékével;

- Egyéni elvárások kielégítése, mind a megjelenés, mind a kialakítás szempontjából. Ez az előző pont kiegészítéseként is tekinthető, hiszen nem csak a méretek és a konstrukció szempontjából történő egyediség megvalósítása fontos, hanem a színek, formák, kiegészítők terén is jó, ha biztosított a felhasználó igényeinek maximális figyelembevétele, és az ezen szempontoknak való megfelelés;

- Összecsukhatóság, akár több irányban: A merevvázas kerekesszékek lapjára csukhatóak, a keresztvázas szerkezetek oldal irányban hajthatóak össze, és vannak olyan darabok, amelyek két irányban is összezárhatóak.

- Egyrészes lábtartó, aminél a két oldali vázrész a lábakat egymáshoz közel tartja, és azok az egybe lábtartón elhelyezkedve nem akadályozzák a felhasználót a szabad mozgásban.

\section{A tartalom és a forma összhangja a kerekesszékek világában}

A különböző kerekesszékfajták az alapvető funkciójuk mellett más-más kiegészítő szereppel rendelkeznek, ami természetesen megmutatkozik a megjelenésükön is. Ezeket a speciális vonásokat, egyedi jellemzőket szeretném most bemutatni.

\subsection{A legegyszerűbb változat: Ápolási kerekesszékek}

A sort a legegyszerúbb, standard főkategóriába tartozó kerekesszékekkel kezdeném. Ezek az úgynevezett ápolási kerekesszékek [2. ábra], amelyek kórházakban, öregek otthonában, egészségügyi létesítmé- 
nyekben, szanatóriumokban, stb. fordulnak elő, ahol nem személyre szabott kerekesszékeket alkalmaznak, hanem egy eszközzel nap mint nap többeket szállítanak egyik helyről a másikra, ezért univerzálisnak kell lenniük.
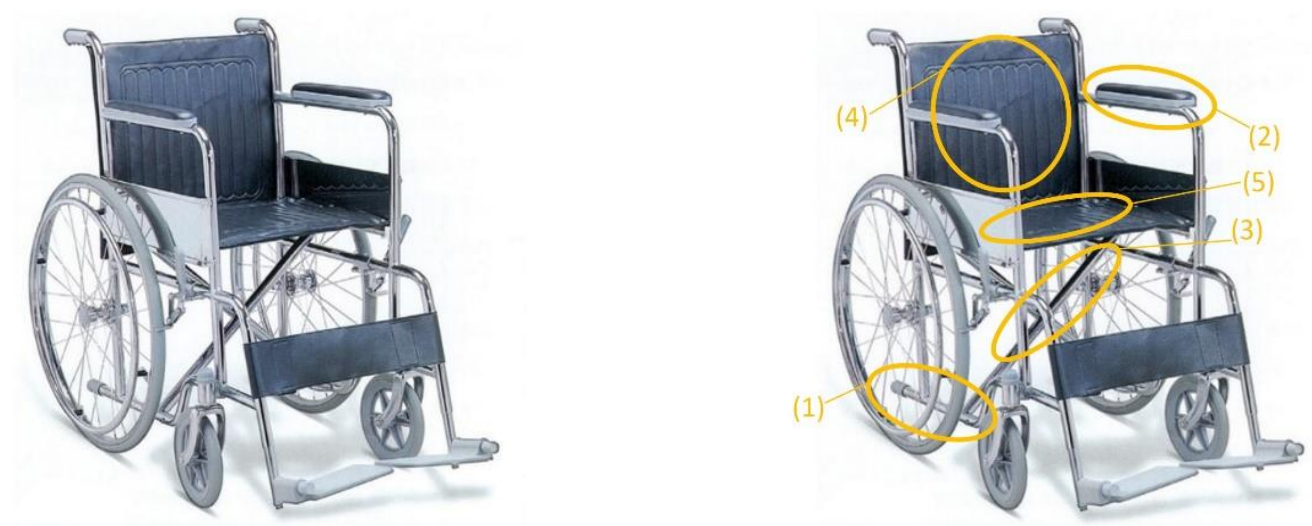

\section{2. ábra. Egészségügyben elterjedt kerekesszék a bemutatott elemek megjelölésével [8]}

Ezek a kerekesszékek kis távok megtételére használatosak, és többnyire a mozgássérült emberek nem magukat hajtják, hanem mások segítségével közlekednek vele.

Ezért is van szükség a képen jól kivehető lépőkarra (1), ami a padkára való könnyebb feljutást teszi lehetővé úgy, hogy a segítő személy erre rálépve könnyebben meg tudja emelni az első kerekeket, így feltolva a padkára a kerekesszéket.

Ezeknél a modelleknél csak a legszükségesebb funkciók találhatók meg, a kényelmet szolgáló extra kiegészítőket nélkülözi, de a fontosabb kényelmi elemeket tartalmazza, mint például a párnázott kartámla (2).

Láthatjuk, a fő tervezési szempont a strapabíró kialakítás, egyszerü használat, olcsó kivitelezés, könnyü tisztíthatóság, stb. volt. A kialakítása ennek megfelelően egyszerü, egyenes vonalvezetésü, öszszecsukható acél csőváz (3) és sík hát- (4), és ülőlap (5) adja konstrukció alapját. A megjelenése egyértelmüen tükrözi, hogy ez egy gyógyászati segédeszköz, ahol a funkció mindenek elött van. Az anyaga rozsdamentes acél, és nylonszövet, ami higiénia szempontjából megfelelőek: a szennyeződések könnyen észrevehetőek, és nagyon fontos, hogy könnyen el is távolíthatóak.

\subsection{Standard kerekesszékek}

Standard kerekesszékekkel nap mint nap találkozhatunk a környezetünkben. A standard kerekesszékek [3. ábra] nem szabhatóak teljesen személyre, csupán a beülőszélesség az, ami hat méretből kiválasztható. Ezen kívül még állítható a lábtartó (1) helyzete, illetve fel is hajtható, ami a székből való kiszállást teszi lehetővé.

A kialakítása és a megjelenése már igényesebb az ápolási kerekesszékekénél. Íves, festett acélvázas kerete (2) is barátságosabb megjelenésü, mint a komor kórházi standard székeké, továbbá az ülése (3) is kényelmesebb kialakítású. A tolókarok (4) markolata ergonómikus kialakítású, ami a segítőnek kényelmesebb fogást biztosít, hosszabb távok megtételénél pedig így kevésbé fáradnak el a kézfej izmai. 

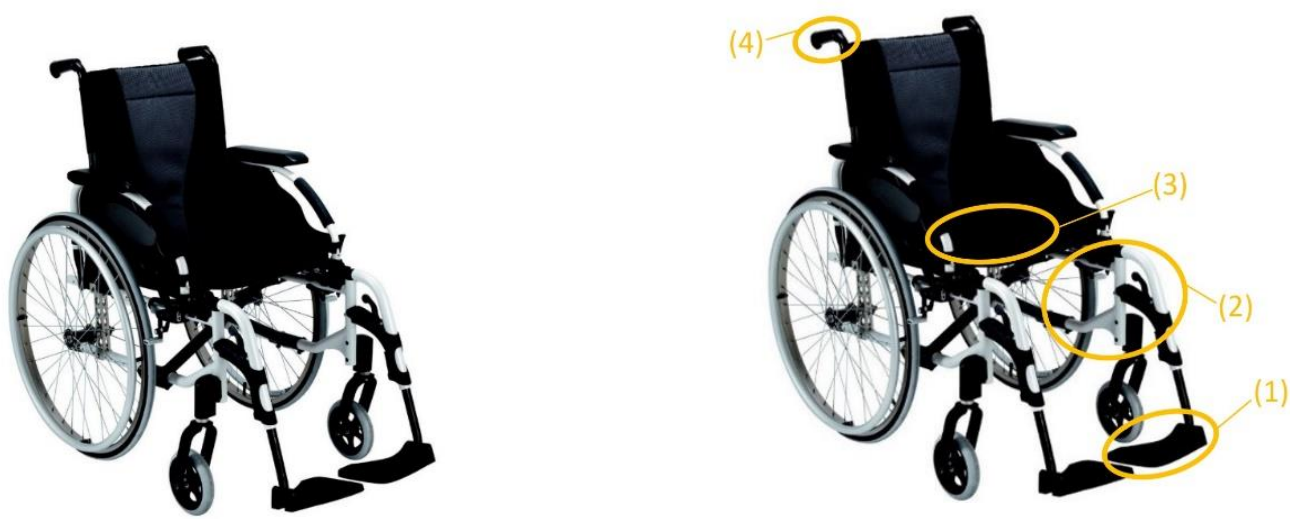

3. ábra. „Hagyományos” standard kerekesszék a bemutatott elemek megjelölésével [9]

\subsection{Aktív emberek kerekesszéke}

A hagyományos, standard kerekesszékeknél speciálisabb eszközök az aktív kerekesszékek [4. ábra], ahol a kialakítás maximálisan támogatja az önálló élet megélését, lehetővé teszi, hogy a felhasználó a lehető legegyszerübben tudja elintézni a mindennapi teendőit, legyen szó akár a lakáson belüli közlekedésről, munkába járásról, gyereknevelésről, vagy akár a szabadidő tartalmas eltöltéséről.

Az aktív kerekesszékek esetében - mivel azok aktív, segítő nélküli életet élő emberek számára lettek kifejlesztve - nincs szükség tolókarokra, sem kartámaszokra. Ez utóbbi ugyan kényelmi szempontból fontos eleme lehetne a berendezésnek, ugyanakkor bizonyos mértékben akadályozza az önálló hajtást, és a folyamatos használat miatt igen ritkán lenne csak szükséges.

Látható még az ábrán a viszonylag hosszú, íves sárvédő (1), ami védelmet nyújt az utcán való közlekedés közben a pocsolyavíz, a sár és a felverődő por ellen.

Szintén újdonság az előző példákhoz képest az egyrészes lábtartó (2), ami a két oldali vázzal együtt egymáshoz közelebb tartja a lábakat, így azok nem zavarják a felhasználót a szabad mozgásban.
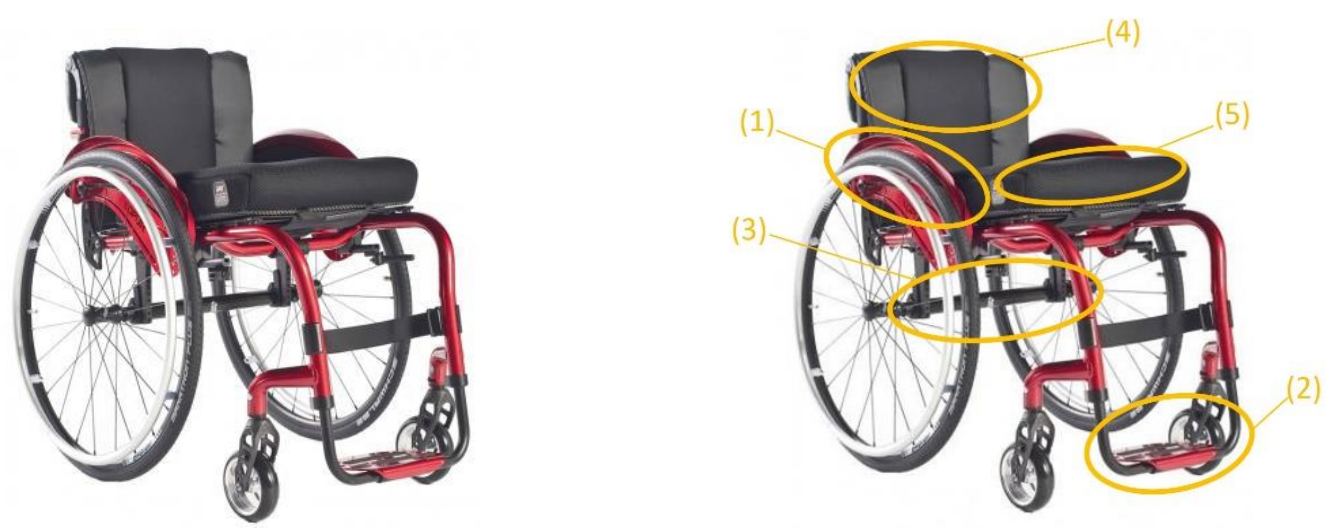

4. ábra. Aktív kerekesszék a bemutatott elemek megjelölésével [10]

Az ábrán [4. ábra] szereplő kerekesszék merevvázas (3), tehát a háttámla (4) az ülőlapra (5) hajtva zárható, oldal irányban nem csukható össze. Ennek előnye, hogy könnyebb összecsukni és szétnyitni, 
ez egyedül is könnyen kivitelezhető, a kerekei pedig egy mozdulattal kivehetőek, így a szállítása is megoldható.

\subsection{Sportkerekesszékek}

A sportkerekesszékek az aktív kerekesszékek egy speciális csoportja.

Egyre nagyobb népszerüségnek örvendenek napjainkban, aminek egyik oka az egészségtudatos életmód terjedése, és hogy egyre inkább kivitelezhető az, hogy a mozgássérült emberek teljes életet éljenek. Habár hazánkban még messze nem tökéletes az akadálymenetesített infrastruktúra kiépítettsége, annak fokozatos fejlödése bizakodásra ad okot.

Az egyre professzionálisabb technikák és anyagok alkalmazása gyors elörelépést hozott a sport-kerekesszékek fejlődésében. A legmodernebb sport-kerekesszékek az egyéb versenysportokban (kerékpár, tenisz, stb.) előszeretettel alkalmazott kompozit és ultra könnyü alapanyagok felhasználásával készülnek.

A kerekesszékekkel üzött sportok listája szinte végtelen, lassan minden sportágnak kialakul a kerekesszékes változata. A sportkerekesszékek széles kínálata közül most a teniszhez kifejlesztett változatot [5. ábra] szeretném bemutatni.
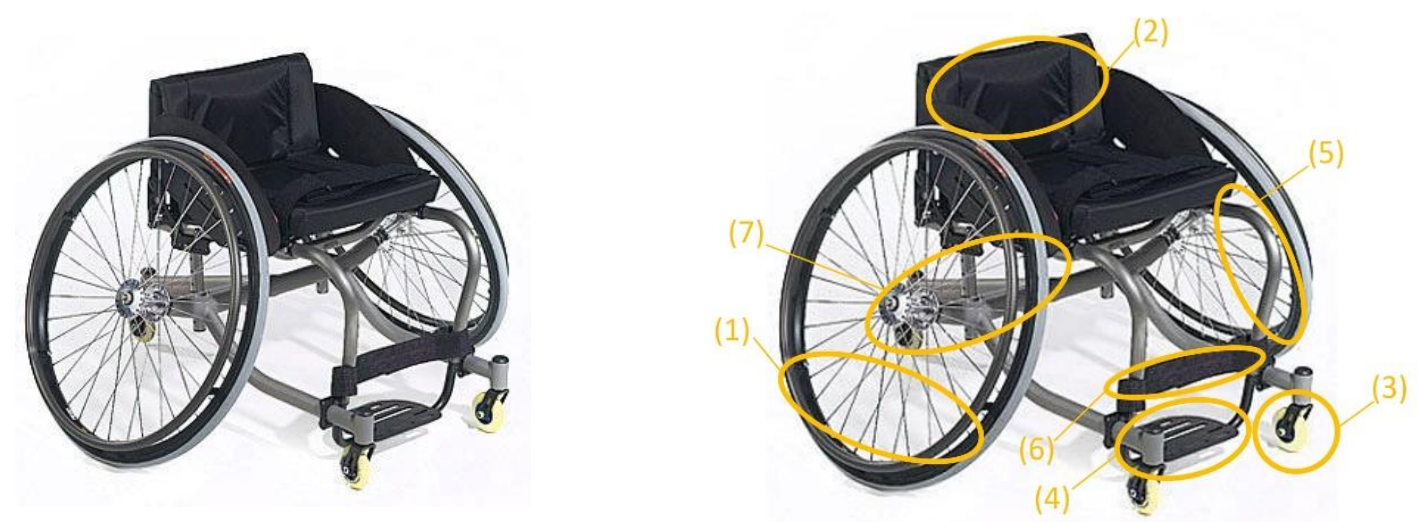

5. ábra. Teniszkerekesszék a bemutatott elemek megjelölésével [11]

Ennek a kerekesszéknek a kialakítása merőben eltérő az eddigiektől. A bedöntött kerekek (1) a gyors helyváltoztatást és a stabilitást szolgálják. Látható még, hogy a háttámlája (2) sokkal kisebb, mint a hagyományos kerekesszékeké, illetve, hogy a tolókarok hiányoznak, hiszen ezt az eszközt sportolók használják edzéseken és versenyeken, amikor is nincs szükségük arra, hogy mások tolják öket. A kartámaszokra szintén nincsen szükség, hiszen a játék közben az csak akadályozná a sportolót.

Kicsi háttámlája is a szabad mozgást hivatott szolgálni, az első, igen kicsi méretü kerekek (3) pedig a kis íves, vagy helyben történő fordulást teszik lehetővé.

A középen elhelyezkedő lábtartó (4), és a hozzá tartozó két oldali váz (5) a lábak egymáshoz közel tartását biztosítják, és szükség esetén hevederrel (6) is rögzíthetők, hogy ne zavarják a sportolót a szabad mozgásban. Szembetünő, hogy itt is csak a legszükségesebb kiegészítők kaptak helyet a szerkezeten, hogy a lehető legkisebb tömeget kelljen mozgatnia az atlétának. Érdemes még megfigyelni a hátsó támasztókereket (7), ami a hátraborulást gátolja meg, így tenisz közben az ütéseket biztonsággal kivitelezhetik, nem kell attól tartaniuk, hogy véletlenül felborulnak. Ez a hétköznapokban használt kerekeszszékeknél hátrány is lehet, hiszen így a kerekesszéket kicsit hátra billentve az első kerekeket nem lehet felemelni, emiatt kisebb padkákra, lépcsőfokokra nem lehetséges az ilyen módon történő feljutás. 


\section{4. Összefoglalás}

A kerekesszékek választéka nagyon gazdag, ráadásul a fejlődésük napjainkban is töretlenül halad előre. Az egyre professzionálisabb anyagok, gyártási technológiák, a személyre szabott kialakítás mind-mind a felhasználó igényeit igyekszik kiszolgálni a mindennapokat megkönnyítve.

\section{Irodalom}

[1] REHAB Termék-Szakkatalógus 2018. I. Kiadás

[2] Cserháti, P.: Kerekesszékben élők nehézségei és lehetőségei; foglalkozási rehabilitáció, autóvezetés, családtervezés; elérési link: file:///C:/Users/user/Downloads/kerszek_cserhati_peter.pdf, felkeresés dátuma: 2019.09.22.

[3] Beal, T. J.: Top tips for wheelchair users, elérési link: https://www.youtube.com/watch?v=kiYWU8gwDBc, felkeresés dátuma: 2019.12.05.

[4] Fenyvesi, Z.: „Ugyanúgy tudok teljes életet élni, mint bárki más”; TV2 Fem3 Café, elérési link: https://www.youtube.com/watch?v=ppDd4Wg4iDk; felkeresés dátuma: 2019.12.02.

[5] Chen, X., Wu, Z., Deng, H.: An Optimization Design for the Standard Manual Wheelchair, elérési link: https://www.diva-portal.org/smash/get/diva2:829505/FULLTEXT01.pdf, felkeresés dátuma: 2019.12.03.

[6] Phisiopedia: Wheelchair Desing, elérési link: https://www.physio-pedia.com/Wheelchair_Design, felkeresés dátuma: 2019.12.05.

[7] https://hdsmedallion.com/blogs/designer-mobility-bags/discover-the-history-of-mobility-devices

[8] https://gyogyaszati.hu/termekek/gyogyaszati-segedeszkozok/3/kerekesszekek-kezi-hajtasu/5/page $=1 /$ kerekesszek-economy-100-kg-ig/756

[9] https://beyr-medical.hu/spd/INV-ACT3/Invacare-Action-3-NG-adaptiv-kerekesszek

[10] http://www.rehabrt.hu/b4215-quickie-ar-aktiv-merevvazas-kerekesszek

[11] https://beyr-medical.hu/spd/INV-ACT3/Invacare-Action-3-NG-adaptiv-kerekesszekk 